\title{
Augmentation of musculoskeletal regeneration: role for pluripotent stem cells
}

\author{
Lauren A Jevons ${ }^{1}$, Franchesca D Houghton ${ }^{*, 1} \&$ Rahul S Tare ${ }^{* * 1,2}$ \\ ${ }^{1}$ Centre for Human Development, Stem Cells \& Regeneration, Faculty of Medicine, University of Southampton, Southampton, \\ SO16 6YD, UK \\ ${ }^{2}$ Department of Mechanical Engineering, Faculty of Engineering \& the Environment, University of Southampton, Southampton, \\ SO17 1BJ, UK \\ * Author for correspondence: Tel.: +44 2381 208731; F.D.Houghton@soton.co.uk \\ ** Author for correspondence: Tel.: +44 2381 205257; R.Tare@soton.ac.uk
}

The rise in the incidence of musculoskeletal diseases is attributed to an increasing ageing population. The debilitating effects of musculoskeletal diseases, coupled with a lack of effective therapies, contribute to huge financial strains on healthcare systems. The focus of regenerative medicine has shifted to pluripotent stem cells (PSCs), namely, human embryonic stem cells and human-induced PSCs, due to the limited success of adult stem cell-based interventions. PSCs constitute a valuable cell source for musculoskeletal regeneration due to their capacity for unlimited self-renewal, ability to differentiate into all cell lineages of the three germ layers and perceived immunoprivileged characteristics. This review summarizes methods for chondrogenic, osteogenic, myogenic and adipogenic differentiation of PSCs and their potential for therapeutic applications.

First draft submitted: 10 August 2017; Accepted for publication: 6 December 2017; Published online: 20 March 2018

Keywords: adipogenesis $\bullet$ chondrogenesis $\bullet$ human embryonic stem cells $\bullet$ human-induced pluripotent stem cells - musculoskeletal regeneration • myogenesis $\bullet$ osteogenesis $\bullet$ pluripotent stem cells $\bullet$ tissue engineering

\section{Socioeconomic burden of musculoskeletal deterioration}

Non-communicable disorders affecting the musculoskeletal system are a major cause of disability and morbidity. A decline in the function of bone, muscle and joint tissues is currently an inescapable consequence of ageing. Due to improved healthcare, longevity has increased; however, while lifespan has improved, a corresponding increase in healthy ageing has not been achieved. As a result, the incidence of musculoskeletal disorders has risen [1]. This has contributed to a huge financial strain on the healthcare systems, as well as on affected individuals [2]. The side effects of these disorders, such as intense and often chronic pain, coupled with decreased mobility, have a dramatic impact on the individual's quality of life. Current surgical and pharmacological treatments are limited in their efficacy [3-6]. Furthermore, the subsequent progressive deterioration of the musculoskeletal system results in an increased risk of falls and fractures $[7,8]$. The natural healing of fractures is often poor in the older population, and carries a higher risk of mortality [9]. Effective treatments for musculoskeletal disorders are therefore necessary to improve the quality of life of our ageing population, and decrease the burden placed on the healthcare system.

\section{Current interventions for the treatment of major musculoskeletal diseases \& their limitations Osteoarthritis}

Osteoarthritis (OA) is the most common joint disease among older adults [10], with a high global prevalence [11] (Table 1). While the percentage of global prevalence remained constant between 1990 and 2010, the years of life lived with disability increased dramatically. Thus, demonstrating the impact of increased lifespan without a corresponding improvement in health span. OA is caused by the degradation of hyaline articular cartilage and the abnormal remodeling of the joint tissues, which results in loss of joint function. Cartilage is avascular, has low cellularity and, therefore, a limited capacity for repair. Daily wear and tear or injury leads to the structural deterioration of articular cartilage at the joint surface. The early stages of $\mathrm{OA}$ are characterized by the formation of partial thickness chondral defects. If left untreated, the defects will extend into the marrow spaces of subchondral 
Table 1. Overview of epidemiology and treatment options for musculoskeletal diseases.

\begin{tabular}{|c|c|c|c|}
\hline Disease & Incidence/risk & Treatments & Drawbacks \\
\hline OA & $\begin{array}{l}\text { - Worldwide incidence of knee OA } \\
\text { estimated at } 3.8 \% \text {, and hip OA } \\
0.85 \%[11] \\
\text { - Lifetime risk of developing } \\
\text { symptomatic knee OA } \sim 40 \% \text { in men } \\
\text { and } \sim 47 \% \text { in women, with higher risk } \\
\text { for obese individuals [30] }\end{array}$ & $\begin{array}{l}\text { Total joint replacement } \\
\text { Reparative techniques: } \\
\text { - Abrasion arthroplasty [14] } \\
\text { - Debridement [15] } \\
\text { - Microfracture [16] } \\
\text { Restorative techniques: } \\
\text { - Mosaicplasty } \\
\text { - ACI [18] } \\
\text { - MACI }\end{array}$ & $\begin{array}{l}\text { Carries some degree of risk [13], } \\
\text { late-stage intervention treatment } \\
\text { Limited repair, and typically results in } \\
\text { fibrocartilaginous tissue } \\
\text { Invasive procedure to procure } \\
\text { chondrocytes, limited cell number, } \\
\text { dedifferentiation during monolayer } \\
\text { expansion, expensive, only recommended } \\
\text { for patients with knee OA with no } \\
\text { previous treatments, fibrocartilaginous } \\
\text { tissue [31,32] }\end{array}$ \\
\hline OP & $\begin{array}{l}\text { - Estimated } 22 \text { million women, and } \\
5.5 \text { million men being affected within } \\
\text { the EU [19] } \\
\text { - Worldwide, OP results in over } \\
8.9 \text { million fractures each year }\end{array}$ & $\begin{array}{l}\text { Pharmacological agents: } \\
\text { Antiresorptive: } \\
\text { - Oestrogen } \\
\text { - Selective oestrogen receptor } \\
\text { modulators } \\
\text { - Bisphosphonates } \\
\text { - Denosumab } \\
\text { Anabolic: } \\
\text { - Full-length parathyroid hormone } \\
\text { (PTH1-8) } \\
\text { - Teriparatide (PTH1-34) } \\
\text { - Strontium ranelate } \\
\text { Other: } \\
\text { - Calcium } \\
\text { - Vitamin D }\end{array}$ & $\begin{array}{l}\text { Long-term administration is required, } \\
\text { which can lead to poor compliancy } \\
\text { Recommendation of taking } \\
\text { bisphosphonate 'drug holidays' to reduce } \\
\text { long-term adverse events can reduce } \\
\text { benefits gained during treatment } \\
\text { periods [33] }\end{array}$ \\
\hline \multirow[t]{3}{*}{ Myopathies } & $\begin{array}{l}\text { - } 4.6 \% \text { of men and } 7.9 \% \text { of women } \\
\text { with a mean age of } 67 \text { in an English } \\
\text { cohort study were diagnosed with } \\
\text { sarcopenia [25] }\end{array}$ & Resistance exercise [35] & $\begin{array}{l}\text { Poor adherence, difficulty to carry out } \\
\text { without assistance due to inherent frailty } \\
\text { of sufferers }\end{array}$ \\
\hline & $\begin{array}{l}\text { - Duchenne muscular dystrophy affects } \\
1 \text { in } 3500 \text { males worldwide [34] }\end{array}$ & Corticosteroids [36] & $\begin{array}{l}\text { Delays symptoms only, multiple known } \\
\text { severe side effects [36] }\end{array}$ \\
\hline & & Genetic interventions [37] & $\begin{array}{l}\text { Large organ to treat. Need to target } \\
\text { skeletal and cardiac muscle. Limited } \\
\text { success [37] }\end{array}$ \\
\hline
\end{tabular}

bone, giving access to bone marrow stem cells (BMSCs). The repair tissue formed by infiltrating BMSCs is typically fibrous rather than hyaline [12].

Effective treatments for OA are currently lacking (Table 1). Total joint-replacement surgery is widely used, however, the surgeries carry significant risks that increase with patient age [13] and are a late-stage treatment option. Early-stage interventions are available and focus on initiating cell-based repair. Reparative techniques such as abrasion arthroplasty [14], debridement [15] and microfracture [16] aim to encourage infiltration of stem cells from the marrow spaces of the underlying subchondral bone, to stimulate repair of the damaged tissue. Restorative techniques such as mosaicplasty [17] involve removing cartilage plugs from non-load-bearing regions of the joint and implanting them into the osteochondral defect zone. Another restorative surgical technique is autologous chondrocyte implantation (ACI) [18]; here, patient-derived autologous chondrocytes are harvested from the nonload-bearing region of the articular cartilage, expanded in monolayer culture and implanted at the site of the defect underneath a periosteal flap. This technique often utilizes a collagen scaffold to support the implanted cells and is referred to as matrix-assisted ACI (MACI). Following recently published NICE guidelines (4th October 2017), ACI is now a recommended treatment; however, patient selection criteria are restrictive. While ACI has been relatively successful compared with other techniques such as mosaicplasty [17], there are a number of drawbacks associated with the treatment (Table 1). 


\section{Osteoporosis}

Osteoporosis (OP) is a prevalent osteodegenerative disease, with an estimated 22 million women, and 5.5 million men being affected within the EU [19]. Worldwide, it is estimated that OP results in over 8.9 million fractures annually (Table 1) [20].

OP is characterized by skeletal fragility, with the hallmark of low bone mass (T-score of -2.5 and below) or a prevalent radiographic vertebral fracture [21]. OP is caused by a disruption in bone turnover homeostasis, leading to accelerated trabecular bone loss that results in a more porous structure. OP is also associated with an increased fall risk and high incidence of fracture [7]. OP predominantly affects the older population, and with increased fracture risk there is a corresponding increase in the likelihood of morbidity. Unlike OA, there are a number of effective pharmacological treatments available for OP (Table 1). Treatment types can be divided into two categories: antiresorptive and anabolic agents. Antiresorptive treatments reduce bone turnover and preserve bone mineral density (BMD). Anabolic agents stimulate bone formation thereby increasing BMD. It has been shown that a combination of these had a synergistic effect on BMD [22]. While these treatments have been suggested to slow the progression of OP, they fail to offer long-term effective solutions [19] and are associated with multiple severe side effects [23,24], and patients are typically subjected to lifelong administration.

\section{Myopathies}

Myopathies (muscular diseases) are another key group of diseases that affect a large percentage of the population [1,2]. A common myopathy is sarcopenia [25] (age-related loss of muscle mass and strength); a disease associated with frailty and has a high incidence in the older population (Table 1). There are also numerous genetic diseases such as muscular dystrophies (MD) [26], for example, Duchene muscular dystrophy (DMD), and limb girdle MD. As with the aforementioned bone and joint diseases, there are limited effective treatments to combat the progression of muscular degeneration. Muscle itself has a resident population of stem cells, known as satellite cells [27]. These cells are responsible for the regeneration of muscle fibers following exercise or injury. However, the satellite cellmediated repair mechanism can become compromised. For example, DMD is characterized by continuous rounds of degeneration and regeneration of muscle fibers that results in a depletion of the muscle stem cell pool [28], leading to a loss of skeletal muscle mass. Currently, there are no approved drugs that consistently result in an increase in both muscle mass and strength making treatment for myopathies extremely limited [29].

\section{Challenges for musculoskeletal regeneration strategies harnessing adult stem cells}

There is a clear paucity in the current available treatments for musculoskeletal diseases, and while for some diseases such as OP, pharmacological interventions have been shown to provide some patient benefit, there is an overall need for improved treatments. Stem cell therapy has emerged as a potential treatment option for a plethora of diseases. However, stem cell therapies are not yet offered as routine treatments for musculoskeletal diseases by health services. Stem cell treatment for musculoskeletal disorders typically utilizes adult stem cells (ASCs; Figure 1) such as bone marrow stromal tissue-derived mesenchymal stem cells (MSCs; synonymously referred to as skeletal stem cells) and satellite cells/myoblasts [38,39]. These SCs are multipotent and, therefore, have a broader treatment potential compared with somatic cells. One of the most widely researched cell types for stem cell therapy are MSCs; these can be obtained from a number of different sites (bone marrow, adipose tissue, muscle, dental pulp and umbilical cord blood) [40] with relative ease, making them a favorable candidate for cell therapy. They are also able to differentiate into many major cell types of the musculoskeletal system due to their mesodermal origin [41]. However, heterogeneity between MSCs from different donors is high [42] as demonstrated by variability between growth properties and osteogenic potential; furthermore, their capacity to proliferate and differentiate declines considerably with increasing patient age $[43,44]$. MSCs are also considered to have an immunomodulatory capacity, and there is evidence to suggest that in vivo their primary function is modulation of repair rather than differentiation into tissue-specific cells, which then contribute directly to tissue regeneration [45].

Injection of undifferentiated MSCs into patients suffering from OA has been shown to improve joint motion and decrease pain [46]. However, another study reported that benefits are transient and that long-term amelioration of the condition is not achieved [47]. Also, MSCs undergoing chondrogenic differentiation (in vitro) have a propensity to become hypertrophic, expressing markers such as type X collagen and alkaline phosphatase [48,49]. Stem cell-based therapies for diseases such as DMD have been prominent research areas for many years. The first stem cell transplant into a DMD patient was performed in 1990 using myoblasts and held great promise for this type of treatment due to the apparent safety of the procedure, and the production of dystrophin (the affected protein in DMD) following 
Blastocyst Inner cell mass

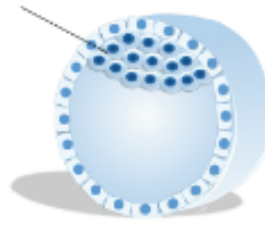

hESC
Patient

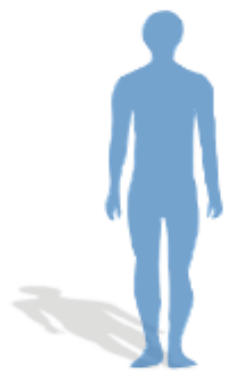

Adult somatic cells

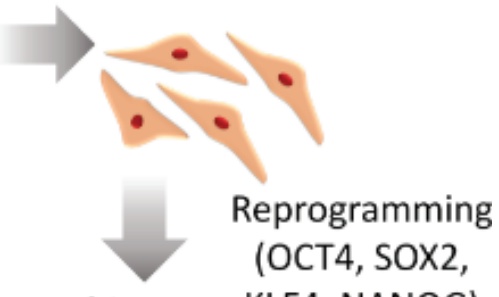

hiPSCs KLF4, NANOG)

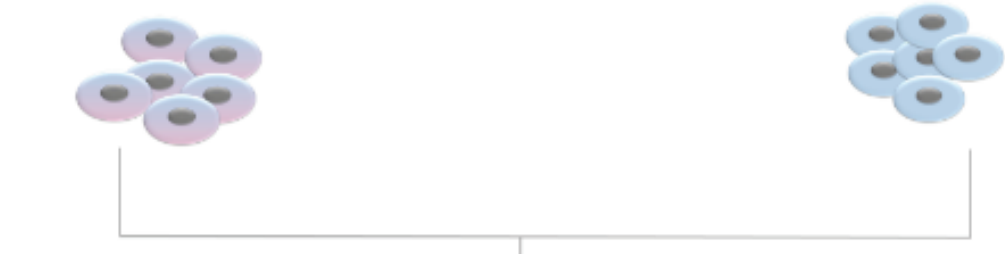

Ectoderm

- Epidermis of skin

- Nervous systems

- Sensory organs

- Pituitary and adrenal medulla

- Jaw and teeth

- Germline cells

\section{Endoderm}

- Epithelium of digestive, respiratory, excretory and reproductive systems

- Thymus, thyroid and parathyroid hormones

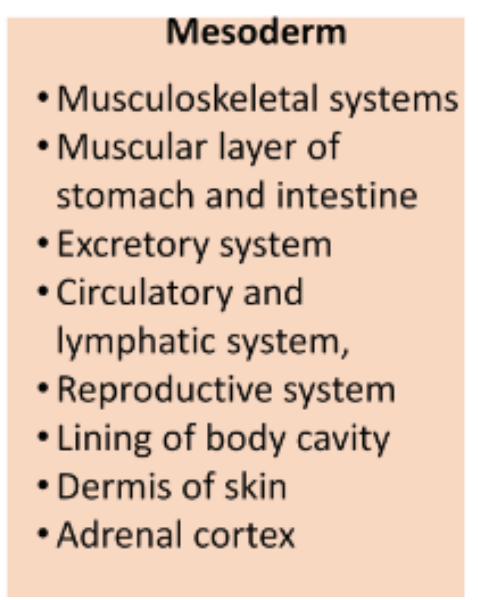

Figure 1. Benefits and drawbacks of using adult stem cells and pluripotent stem cells for clinical applications. Comparison of the advantages and disadvantages of BM-MSCs, hESCs and hiPSCs for application in regenerative medicine.

BM-MSC: Bone marrow-derived mesenchymal stem cell; hESC: Human embryonic stem cell; hiPSC: Human-induced pluripotent stem cell.

transplantation [39]. However, in subsequent clinical trials, the results were inconsistent, with some, but not all, reporting dystrophin production and no significant clinical benefits [50,51].

While MSC/ASC therapy is an appealing prospect, it is clear that its application is problematic. One major drawback of using ASCs is that in order to prevent an immunological response, the cells must be autologous (patient derived), which can be challenging due to potentially low cell numbers, poor viability due to age and disease state. There is also the potential for donor site morbidity.

\section{Pluripotent stem cells: a promising alternative for musculoskeletal regeneration}

It is of significant clinical benefit to develop a method of restoring damaged tissue that maximizes quality of repair and minimizes the risk to the patient. To this end, there has been a surge of interest in the potential of pluripotent 


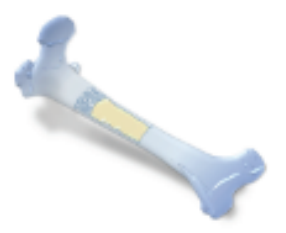

\section{Adult SC eg. BM-MSCs}

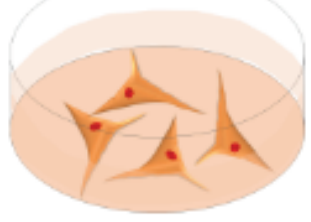

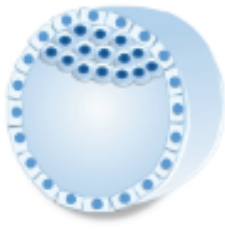

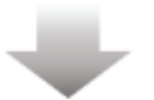

hESC

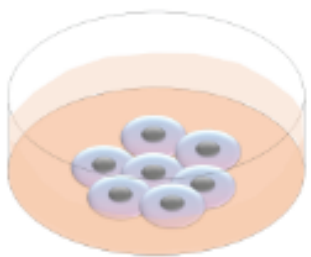

- Pluripotent

- Allogenic

- Extensive proliferation without senescence

- High yield

- Possible immunogenicity

- Ethical considerations

- Risk of teratomas
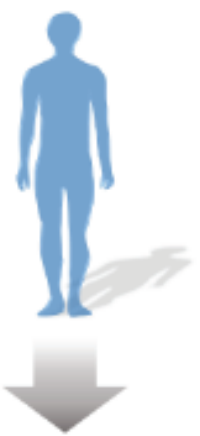

hiPSC

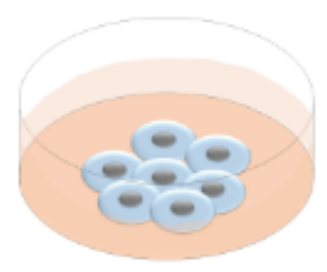

\section{Drawbacks \\ - Limited proliferation and differentiation capacity \\ - Senescence \\ - Heterogeneity \\ - Low yields}

- Pluripotent

- Autologous

- Extensive proliferation without senescence

- High yield

- Low reprogramming efficiency

- Epigenetic memory

- Risk of teratomas

Figure 2. Derivation of pluripotent stem cells and subsequent tissue generation ability. hESCs can be derived from the inner cell mass of a blastocyst at the final stage of preimplantation development. hiPSCs can be reprogrammed from somatic cells using the forced expression of OCT4, SOX2, KLF4, NANOG. These cells can subsequently be differentiated into any derivative of the three germ layers (ectoderm, endoderm and mesoderm). hESC: Human embryonic stem cell; hiPSC: Human-induced pluripotent stem cell.

stem cells (PSCs) for the treatment of skeletal disorders. PSCs have the ability to differentiate into all three germ layers (endoderm, mesoderm, ectoderm; Figure 2) and can, therefore, provide a source for any somatic cell in the body. PSCs can also proliferate indefinitely in vitro, without showing signs of cellular senescence. Therefore, PSCs have tremendous potential as a viable source of cells for musculoskeletal repair as they can be differentiated into cells of the mesodermal lineage, and therefore have the potential to generate tissues such as cartilage, bone, muscle and fat for clinical application (Figure 3). 


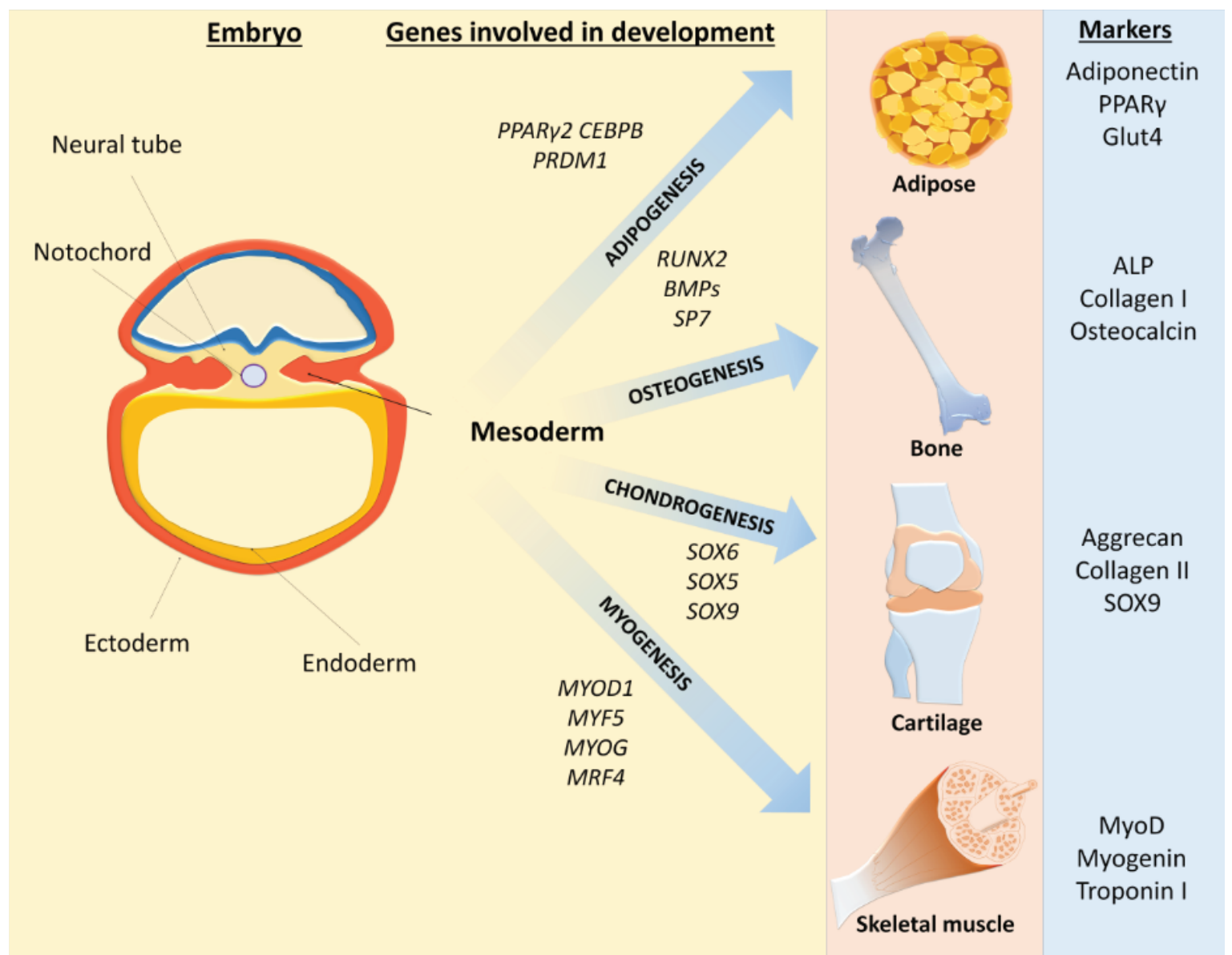

Figure 3. Differentiation of mesoderm into adipose, bone, cartilage and skeletal muscle during development. During embryonic development, the embryo undergoes gastrulation and forms three germ layers: ectoderm, endoderm and mesoderm. The mesoderm gives rise to musculoskeletal tissues via the activation of key genes. In developed tissues, specific proteins can be used as markers.

There are two distinct types of PSCs, embryonic and induced PSCs (iPSCs; Figure 1). Embryonic stem cells (ESCs) are derived from the inner cell mass of the blastocyst [52], and were the only known source of PSC until 2006 when Takahashi and Yamanaka developed a technique of reprogramming somatic cells into iPSCs [53], for which Yamanaka was awarded the Nobel Prize. iPSCs offer the potential for personalized regenerative medicine therapy as they can be derived from the patient's own cells. More recently, multilineage differentiating stress enduring cells have been discovered as a potential source of PSCs within adult tissues [54]. Multilineage differentiating stress enduring cells are found within most adult connective tissues, are able to withstand extreme stress, express markers for pluripotency and can be isolated by SSEA-3 expression.

\section{Human ESCs}

Human ESCs (hESCs) were first derived in 1998 by Thomson et al. [52]. These cells derived from the preimplantation or peri-implantation embryo display prolonged undifferentiated proliferation, and stable developmental potential to form derivatives of all three embryonic germ layers even after prolonged culture [52]. This pluripotent potential can be tested in vitro via embryoid body (EB) formation, or in vivo via teratoma formation.

Since their discovery, hESCs have been heralded as a potential panacea for regenerative medicine. However, there has also been some debate over whether or not hESCs present an immunogenic risk. There is evidence to suggest that hESCs trigger an immune response [55], however, there is also contrasting evidence to suggest that they are immunoprivileged [56], or have negligible immunogenicity [57]. If hESCs do indeed elicit an immune response, this would hinder clinical application. Banks of clinical-grade hESC lines that can be human leukocyte antigen-matched to groups of individuals could ameliorate potential issues with immunogenicity and make hESCs a viable option 
for regenerative medicine [58]. However, the additional challenge of aneuploidy arising from prolonged culture of hESCs is an issue that must be addressed before clinical application of hESCs [59].

Just 12 years after their discovery, hESCs were used in a clinical trial. Geron used hESCs for treatment of spinal cord injuries, however, this trial was prematurely halted [60]. Current trials are underway for the treatment of Stargardt's macular dystrophy, dry age-related macular dystrophy and diabetes [60,61].

\section{Induced PSCs}

Human iPSCs (hiPSCs) were first generated via the reprogramming of somatic cells to a pluripotent state by overexpressing a set of key transcription factors: OCT3/4, SOX2, KLF4, and C-MYC [62]. iPSCs have been found to be similar to hESCs in their morphological characteristics, self-renewal capacity, differentiation potential and gene expression profile (although there is some controversy regarding the latter [63]). The use of the patient's own cells place iPSCs at the forefront of personalized medicine by overcoming the possible immunogenicity of ESCs. The reprogramming of the cells was initially performed via retroviral or lentiviral transduction of the key factors. However, reprogramming efficiencies are low, and the process of creating patient-specific cell lines slow and costly. A further significant drawback is the potential for insertional mutagenesis, tumor formation and genetic dysfunction.

To overcome these limitations, non-integrating adenovirus, sendai virus, episomal vector or completely DNAfree techniques have been developed [64-67], with the first in-human iPSC clinical trial taking place in 2014 [68]. The successful implantation of iPSC-derived retinal pigment epithelium cells into a patient with age-related macular dystrophy was reported; however, the trial was prematurely suspended when it was found that the second patient's differentiated cells contained multiple mutations [60]. This raises important safety concerns. It has been suggested that an alternative trial using allogeneic hiPSCs may be a possibility [60].

While iPSCs display many of the characteristics of ESCs such as high proliferation under continuous culture without senescence, and the ability to form teratomas in vivo, there are also some fundamental differences. Once reprogrammed, iPSCs retained the epigenetic signature of the somatic parent cell [69], and exhibited altered methylation patterns in some of the key pluripotency genes such as Oct4 [63]. This 'epigenetic memory' can influence the behavior of the reprogrammed cells by directing them toward their lineage of origin, and thus affecting their potency. This could potentially hinder attempts to differentiate iPSCs toward a designated lineage for clinical applications.

A comparison of the benefits and drawbacks of different SC sources is shown in Figure 1. Over recent years, much research has concentrated on the development of potential treatments for musculoskeletal disorders using PSCs.

\section{PSCs \& chondrogenic differentiation}

\section{Chondrogenesis in EBs}

There are numerous techniques that have been developed to induce the in vitro differentiation of PSCs into chondrocytes. One method is via the formation of embryoid bodies [70,71]. One study found that hypoxia and morphogenetic factors had synergistic effects on chondrogenesis in EBs [71]. It is established that ESCs are more pluripotent when cultured under hypoxic conditions [72], and in vivo cartilage is subjected to hypoxia, and thus may account for the enhanced chondrogenesis observed under hypoxic conditions. While the 3D environment of EBs partially recapitulates the in vivo developmental process, the resulting cell population is typically heterogeneous due to the emergence of endoderm and ectoderm lineage-derived cells as well as the desired mesoderm, making downstream processes such as cell sorting essential for achieving a purer cell population. Interestingly, the ability of the TGF- $\beta$ family to induce chondrogenic differentiation in EBs has produced conflicting results, with inhibitory effects when added at some stages of EB differentiation [70,73,74]. This is despite the TGF- $\beta$ family being potently prochondrogenic, something that remains true during MSC differentiation [75]. This highlights the distinct differences that exist between ASCs and ESCs in terms of chondrogenic differentiation, and gives an insight into the potential complexity of generating chondrocytes from PSCs. Chondrogenic differentiation of EBs has been achieved via various culture methods, such as pellet or micromass culture [71] methods, also used for cartilage generation using primary chondrocytes and MSCs [76].

As with ESCs, it has been shown that iPSCs can be used to generate EBs, which could subsequently be directed to differentiate into cartilaginous tissue [77]. Reprogrammed osteoarthritic-chondrocytes have also been used to generate hiPSCs, and subsequently differentiated to chondrocytes using TGF- $\beta 1$ supplementation [78]. Cartilage markers, namely, type II collagen and aggrecan, were expressed by the differentiated hiPCs. This could indicate 
that retaining an epigenetic memory may be beneficial for differentiation. However, it is beneficial to have an understanding of the iPSC methylation state as altered methylation patterns in certain genes, such as COL1OA1, can be beneficial in promoting chondrogenesis and preventing hypertrophy [79].

\section{Chondrogenesis in co-cultures}

An alternative differentiation method is to co-culture PSCs with mature chondrocytes. This co-culture can be either direct or indirect $[80,81]$. In each case, secreted factors from the adult chondrocyte population created an extracellular milieu that enhanced chondrogenic differentiation. One of the factors secreted by mature chondrocytes is parathyroid-related hormone that plays an important role in chondrogenesis and the prevention of hypertrophy [82]. Fibrocartilaginous differentiation has also been shown using hESCs separated from a fibrocartilage-derived chondrocyte cell layer via nylon cell strainers; here indirect co-culture was combined with growth factor supplementation (BMP-4, TGF- $\beta 3$ ), which improved differentiation significantly [83]. Direct co-culture in the form of high-density pellet culture of hESCs with mature chondrocytes was also shown to enhance differentiation along chondrogenic lines [84]. However, clinical applications of these methods would be difficult due to the need for an autologous chondrocyte population. Furthermore, these culture systems are difficult to scale up as larger cultures often result in poor nutrient diffusion leading to necrotic cores $[85,86]$.

\section{Chondrogenesis via MSC intermediates}

Another technique involves differentiating hESCs, or hiPSCs, into chondrocytes via MSC intermediates. hESCs cultured on a monolayer of murine OP9 cells were differentiated toward MSCs [87]. The cells were analyzed following 40 days of culture, and $\mathrm{CD} 73^{+}$cells were replated without a feeder layer. These cells were found to express adult MSC markers, and were subsequently successfully differentiated along chondrogenic, osteogenic, adipogenic and myogenic lineages [87]. However, due to the initial use of an animal feeder layer, this method of deriving ESC-MSCs is not clinically compliant and thus may introduce xenoantigens. Clinically compliant MSCs have been derived from hESCs [88]. Cells expressed MSC antigens and gene expression profiles similar to BM-MSCs and could be differentiated into chondrocytes. The hESC-derived MSCs were able to proliferate in vitro for at least 35 population doublings without developing any karyotypic abnormalities that would normally occur in in vitro cultures of BM-MSCs. This suggests that hESC-derived MSCs may have a much more robust karyotype than adult BM-MSCs.

\section{Chemically defined methods for chondrogenesis}

While the aforementioned methods have demonstrated success in the derivation of chondrocytes from PSCs, few systems were clinically compliant. For clinical applications, a fully defined feeder/serum-free culture method is required. To this end, Oldershaw et al. [89] have developed an effective, chemically defined protocol for deriving chondrocytes from hESCs [89,90]. This protocol is based on the sequential signaling pathways involved in the developmental process of chondrogenesis. Growth factors are used to direct differentiation of the hESCs toward chondrocytes over the course of 14 days. A substantial expansion of the cell population was reported during the differentiation protocol (8.5-fold), and between 75 and 97\% SOX9-positive cells were obtained with four different hESC lines [91]. The protocol was also applied to two iPSC lines with similar success [91]. Following the 14 day protocol, there was no evidence of pluripotent cells remaining; this was particularly encouraging as residual pluripotent cells following transplantation could result in teratoma formation. This high efficiency and purity makes this a potentially useful protocol for both clinical and laboratory applications. To test the potential for clinical application of this technique, hESC-derived chondroprogenitors embedded in a fibrin gel were transplanted into an osteochondral defect in athymic RNU rats [91]. The transplanted cells formed hyaline cartilage, identifiable from 4 weeks, and fully developed by 13 weeks postimplantation. Defect repair was significantly improved by ESC-derived chondroprogenitors, compared with fibrin-only controls, and they reported significant cell survival of the transplanted population. However, as an osteochondral defect model was used here, it is unclear whether the repair was orchestrated by the implanted cells or the resident SCs from the bone marrow cavity. 


\section{PSCs \& osteogenic differentiation}

\section{Osteogenesis in EBs}

As with chondrogenesis, early methods of in vitro osteogenic differentiation from PSCs involved EB formation from ESCs and iPSCs $[92,93]$. However, enhanced osteogenic differentiation has been reported to occur without EB formation [94].

Early studies that utilized EB formation generally relied on in vitro assays to study the extent of osteogenic differentiation. However, the reliability of such assays is questionable as they frequently yield positive results despite only a small percentage of cells having been differentiated along the osteogenic lineage. One technique that is used to overcome this is use of flow cytometry to isolate osteoblast cells using lineage-specific markers; however, the markers used for isolation vary between groups. Incorporation of fluorescent reporters such as Col2.3GFP (2.3 kb fragment of the rat Collal promoter) [95] has improved this technique and helped to reduce variation between research groups. Despite this improvement, in vitro assays are still not a reliable predictor of bone formation [96]. Techniques such as organotypic culture, and in vivo ectopic bone formation are more robust measures of osteogenic capacity.

\section{Osteogenesis in co-culture}

Osteogenic differentiation of hESCs has also been shown using direct and indirect co-culture with a variety of different cell types.

Direct co-culture of EBs with primary bone-derived cells was performed, after 14 days of co-culture mineralization and nodule formation was detected [97]. During direct co-culture with human periodontal ligaments fibroblasts in vitro mineralization occurred, suggesting that human periodontal ligaments fibroblasts have osteogenic-inducing potential [98].

Indirect co-culture of hESCs has also been performed using the transwell co-culture system [99]. Osteogenic differentiation of EBs was induced by the addition of osteogenic medium. Indirect co-culture with human bone marrow stromal cells (hBMSCs) for 28 days was then initiated 7, 14 or 24 days postdifferentiation. While there was a slight trend toward increased mineral deposition following co-culture compared with controls, the difference was not statistically significant. Furthermore, expression of the osteoblastic markers were more pronounced in hESCs exposed to osteogenic culture medium without co-culture, compared with hESCs co-cultured with differentiated hBMSCs. It is difficult to determine to what extent, if at all, co-culture with hBSCs was beneficial as there did not seem to be any significant improvement in osteogenic differentiation compared with supplementation with osteogenic media alone.

An interesting alternative to traditional co-culture techniques involves culturing hESCs with an autologous osteogenic-inducing culture supplement extracted from hESC-derived osteogenic cells [100]. This novel approach was devised in order to overcome the cost associated with large-scale bioreactor cultures for commercial applications, as the resultant cost of supplementing cultures with growth factors, cytokines and extracellular matrix (ECM) would prove to be prohibitively expensive. Here, a proof-of-principle investigation was performed to demonstrate a potential alternative to culture supplementation proposed to be useful for clinical application. They found that the whole-cell lysate from hESC-derived osteogenic cells promoted aggregation of the hESCs into nodules, and enhanced in vitro osteogenic differentiation compared with controls. However, due to the costs that would arise from serum-free culture, they used animal products in their cell culture media. This would have to be addressed for clinical translation.

\section{PSCs \& myogenic differentiation}

Transplantation of myoblasts from satellite cells or other myogenic populations has been attempted in an effort to treat diseases such as MDs [101-103]; while this work has been promising, the drawbacks of using ASCs prevail. Transplantation of PSC-derived satellite cells into muscle is appealing as this could help simultaneously replenish a depleted resident satellite cell pool, as well as regenerate the muscle tissue itself.

Unlike chondrogenesis and osteogenesis, it has proved very difficult to induce in vitro myogenesis via EB formation. While it has been shown that the early stages of myogenesis occur in EBs [104,105], generating cells with the desired regenerative capacity for tissue engineering purposes have proved elusive. It has been postulated that this is because in vitro cultures do not form the notochord or neural tube, and so the key signaling events that are orchestrated by these structures in vivo cannot occur [106]. 


\section{Myogenesis in co-culture}

Techniques such as co-culture [87,107], and the addition of myogenic medium [108] have demonstrated some success in deriving myogenic cells from ESCs, and have shown some evidence of engraftment when the cells were transplanted into mice [108]. However, assessments were limited to qualitative detection and did not assess the functional capabilities of the engrafted tissue.

\section{Myogenesis via genetic manipulation}

An effective myogenic differentiation method includes the application of genetic manipulation techniques to induce expression of myogenic master regulators Pax3 or Pax7 [106] during development of early mesoderm. This bypasses the requirement for early inductive signals from the notochord and neural tube, and provides a method for generating larger quantities of myogenic progenitors, compared with non-genetic techniques. Cells derived from both ESCs and iPSCs have been transplanted into models of MD with some success, demonstrating an overall improvement in functional capacity in terms of muscle force generation [106,109-111]. Myogenic induction of ESCs and iPSCs has also been shown by inducing expression of Met Activating Genetically Improved Chimeric Factor-1 [112]. The myogenic regulatory factor Myo-D has also proved to be useful for the induction of myogenesis in iPSCs [113]. Here, transplantation of the differentiated cells ameliorated the dystrophic phenotype, restored depleted progenitors and improved functional capacity of the muscle. This method could potentially be used to treat various different forms of MD in humans, with the aspect of gene correction offering a personalized approach for patients with inheritable diseases.

While PSCs are particularly amenable to genome editing as they are able to undergo multiple culture manipulations without losing their pluripotency, this method of derivation can be extremely time consuming, and the use of certain vectors carry risks such as mutagenesis, and therefore limit their clinical use. Excisable, non-integrating vectors overcome these issues but are typically less efficient. However, use of animal sera remains an issue, as serum is frequently used as a stimulus for terminal myogenic differentiation [106,110,111], and is therefore a limiting factor in clinical application.

\section{Myogenesis via MSC intermediates}

As with chondrogenesis and osteogenesis, MSCs have also been derived from PSCs to facilitate myogenesis. Multipotent iPSC-derived MSCs have been demonstrated to attenuate limb ischemia in mice [114]. Transplantation of iPSC-derived MSCs via intramuscular injection was found to increase myogenesis and neovascularization, and improve limb function compared with injection of BM-MSCs or vehicle only.

Epigenetic memory of iPSCs is often considered to be disadvantageous when comparing iPSCs and ESCs. However, as previously mentioned with regard to in vitro chondrogenesis, epigenetic memory of the parent cell may improve differentiation of the iPSC; this phenomenon has also been reported for iPSCs derived from mesangioblasts [115], suggesting a more robust myogenic lineage commitment when iPSCs are derived from the same lineage.

\section{PSCs \& adipogenic differentiation}

Adipose tissue is generally thought to develop from the mesoderm. The ability to derive white adipocytes (the most abundant fat cell type in the body) in vitro from stem cells would be of particular benefit to patients requiring surgical reconstruction of soft tissues, something that is often required following trauma caused by disease or injury. Application of PSC-derived adipose tissue would be of significant benefit to patients as current reconstructive methods such as autologous grafting can result in donor site morbidity [116].

\section{Adipogenesis in EBs}

In vitro adipogenesis from PSCs has so far relied on the generation of EBs from ESCs and iPSCs, and subsequent differentiation into adipocytes [117-119]. Retinoic acid (RA) is well documented as being an inducer of adipogenesis. Using RA as the differentiation stimulus, a comparison of the adipogenic potential of ESCs and iPSCs has been performed [119]. The authors reported no significant variation between the adipogenic potential of hESCs and hiPSCs overall, however, there was heterogeneity between different iPSC cell lines, despite having the same genetic origin. While RA has been shown to have potent effects on adipogenic differentiation, it is not a standard component of adipogenic medium. Other growth factor combinations such as BMP-2, TGF-ß1, insulin and ascorbic acid are more commonly used [120]. 


\section{Adipogenesis via genetic manipulation}

Another method for inducing adipogenic differentiation in PSCs is to use genetic reprogramming techniques to induce expression of genes involved in adipogenesis. Brown adipose tissue is far less abundant within the body and functions to produce heat through non-shivering thermogenesis. It has been discovered that adults have depots of brown adipose tissue that are inversely correlated in size with BMI [121-123]. This finding has led to considerable interest in the potential therapeutic benefits of brown adipocytes. Retroviral transduction of the PPAR $2, C E B P B$ and PRDM1 genes into hESCs and hiPSCs has been shown to induce adipocyte differentiation into brown adipocytes [117]. Here, the authors found variable adipocyte differentiation potential between cell lines and also reported that efficiency was less in PSCs compared with adipose-derived stromal vascular cells. However, following derivation of both white and brown adipocytes, it was found that in vivo transplantation resulted in the formation of tissues with functional and morphological similarities to primary cells, and importantly they reported no teratoma formation after 4-6 weeks.

\section{Adipogenesis via addition of growth factors}

Differentiation into functional brown adipocytes has also been achieved without exogenous gene transfer [118]. Supplementation with the cocktail comprising of KITLG, IL6, FLT3LG and VEGF was found to be essential for brown adipose differentiation of hPSCs, both hESCs and hiPSCs. One of their most interesting findings was that inhibitor analyses revealed that p38 MAPK signaling played a role in brown adipose differentiation in hESCs, but MEK signaling did not; however, in hiPSCs MEK signaling was involved in differentiation. This highlighted a distinct difference between hiPSC and hESC-derived brown adipocytes.

\section{From cell-based strategies to tissue engineering 3D constructs}

Cell-based therapies for regenerative medicine have not yet demonstrated a full restoration of the damaged tissue to its original state. A tissue engineering approach provides an alternative method to introducing differentiated cells directly into damaged tissue, which incorporates cells, appropriate growth factors, biomaterial scaffoldbased/scaffold-free approaches in combination with bioreactor technology to generate a 3D issue construct in vitro, before implantation. Thus, mitigating the risk of transferring undifferentiated cells to the patient. 3D culture also aims to recapitulate the in vivo environment and facilitates the successful generation of tissues such as cartilage, bone and muscle in vitro. Furthermore, this approach ensures that suitable tissue constructs with the appropriate physiological and biomechanical properties are formed, thus providing a level of control that is not possible with cell transplantation.

The use of biomaterial scaffolds in the generation of cartilage tissue is well documented [78-81,84,91], and shares similarities with current clinical interventions for OA (MACI). However, since the native tissue has a low capacity for self-repair, it is desirable to create in vitro constructs that are functionally and morphologically identical to native cartilage to improve the ease of integration. Scaffold-free techniques for cartilage tissue engineering have been successful in producing in vitro cartilage constructs via chondrogenic differentiation of hPSCs in 3D pellet culture $[71,79,81,84,87]$. However, limited testing of these cartilage constructs has been performed in a physiologically relevant environment, for example, load-bearing animal model. In one study, hiPSC-derived cartilage pellets were shown to promote healing when introduced into osteochondral defects in the palate groove of immunosuppressed rats [79].

Unlike cartilage which has a very limited capacity for self-repair, bone is a dynamic tissue that is constantly undergoing remodeling and has a much higher repair capacity. Here, scaffolds and various biomaterials have provided an invaluable tool for bone tissue engineering as they can enable a greater level of control over form and structure, and can also be supplemented with osteoinductive agents. Mineralized tissue formed by differentiated PSCs has been shown using various different scaffold materials [93,124-127]. In these studies, the engineered tissue was subcutaneously implanted in animal models and in vivo mineralization capacity was evaluated; however, there is a lack of studies that have investigated the in vivo reparative effects of the PSC-derived engineered tissue. A stumbling block for bone tissue engineering is the inability to generate/bioengineer a functional blood supply.

For skeletal muscle and adipose tissue trauma such as volumetric muscle loss, or damage that occurs as a result of surgical procedures, tissue engineering using scaffolds has been shown to be of significant clinical benefit [128]. Tissue engineering for such purposes may be either in vitro or in vivo. There are numerous difficulties associated with in vitro construct formation, for example, producing large enough constructs for the affected area takes a long time. It is also difficult to attain good vascularization of muscle constructs and physiologically relevant contraction 


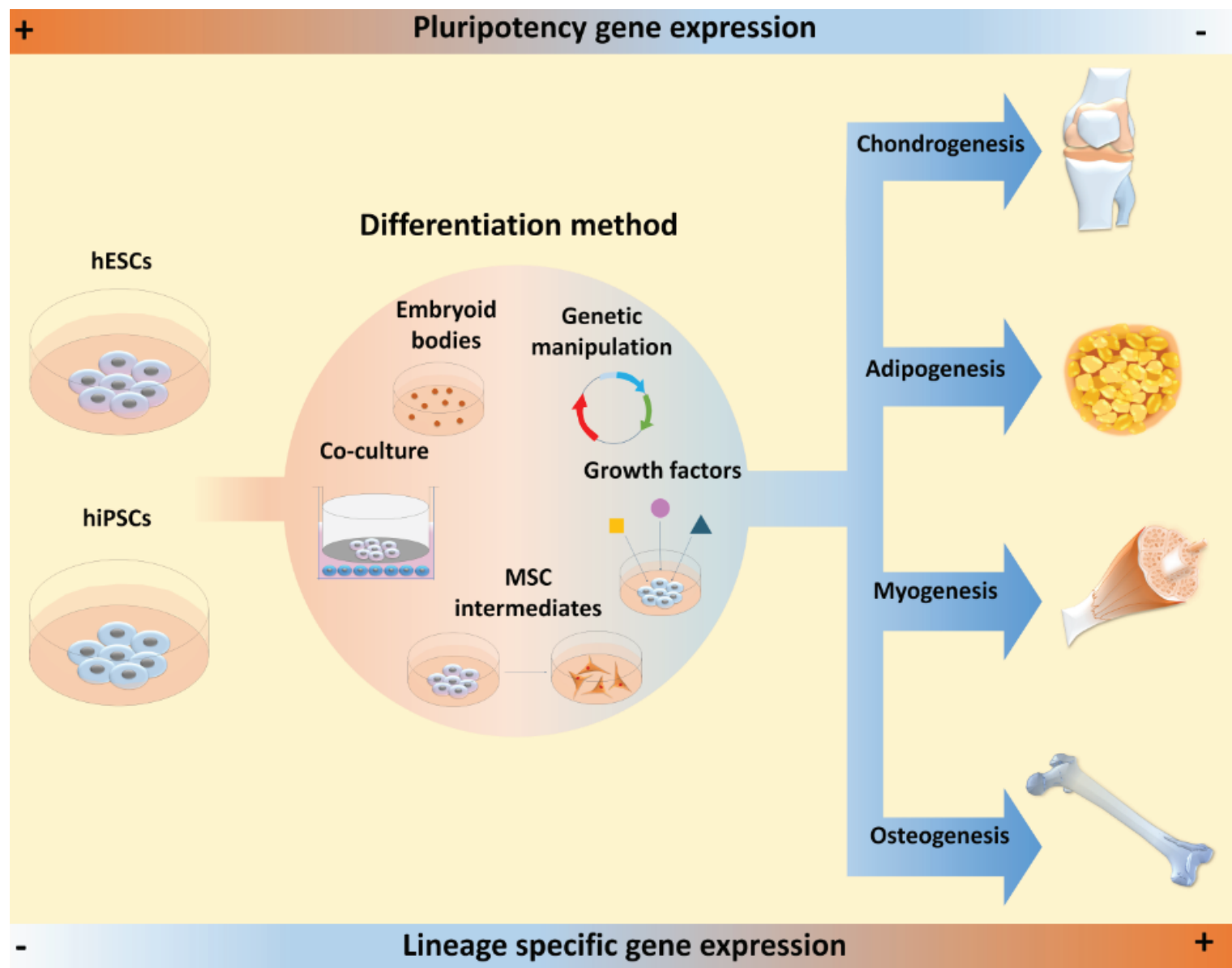

Figure 4. Schematic summarizing methods used to generate cells of mesodermal lineages, namely, chondrogenic, adipogenic, myogenic and osteogenic, from human embryonic stem cells and human-induced pluripotent stem cells. A wide range of methods, including embryoid body generation, genetic manipulation, application of appropriate growth factors, co-culture and differentiation via MSC intermediates, have been applied to generate chondrogenic, adipogenic, myogenic and osteogenic lineages from hPSCs for musculoskeletal regeneration.

hESC: Human embryonics stem cell; hPSC: Human pluripotent stem cell; MSC: Mesenchymal stem cell.

forces. The in vivo approach to muscle and adipose generation is, therefore, generally more favorable. Here, cells are transplanted with, or into, a biomaterial scaffold that can integrate with the host tissue and form a niche where tissue regeneration may occur [128].

\section{Conclusion \& Future perspectives}

Musculoskeletal regeneration has become a prominent research area, no doubt due to the sociological and economic pressures imposed by the current ageing population. The ability of PSCs to self-renew and differentiate into any somatic cell type may well prove to be a highly effective tool in the treatment of such diseases. With regard to iPSCs, their potential is irrefutable, and the opportunity to derive allogenic cells from patients is extremely enticing. However, several issues remain to be addressed, such as the efficiency of reprogramming using non-viral vectors and the impact of 'epigenetic memory' on therapeutic treatments. In contrast, hESCs are not associated with these problems.

Regarding differentiation protocols, cells of mesodermal origin have been derived via a variety of methods (Figure 4); however, it is clear that there is a requirement for clinically compliant, chemically defined methods of deriving specific cell types while keeping costs as low as possible. This review has gone some way toward showing that such protocols are a possibility, for instance, Oldershaw et al. developed a protocol for the directed differentiation of hESCs/hiPSCs to chondrocytes that resulted in a high cell yield, and was fully chemically defined which would ease generation of a clinically compliant protocol [89]; however, to make such treatments accessible, cost would 
likely remain an issue. It is also prudent to acknowledge that protocols using PSCs to derive cells for application in drug testing, for example, myogenic progenitors and myotubes [129], are also of value for tissue engineering and knowledge gained from such studies is of significant value to the field.

Treatment approaches in the future are likely to focus on tissue engineering as this would enable the existence of a quality control system, whereby $3 \mathrm{D}$ explants that are generated can be assessed in terms of their morphological, mechanical and physiological properties prior to implantation. Use of bioreactors is likely to increase in popularity as they allow for precise and accurate manipulation of environmental factors that allows for a more physiological culture setting. However, for clinical purposes, more high-throughput systems will ultimately be required. Importantly, to fully elucidate the functional capacity of tissue-engineered musculoskeletal constructs, it is vitally important that these are tested in appropriate in vivo models, and the parameters relating to their function are fully assessed.

\section{Executive summary}

Socioeconomic burden of musculoskeletal deterioration

- Diseases affecting the musculoskeletal system are a major cause of disability and morbidity.

- Effective long-term treatment options are lacking, resulting in increased strain on healthcare systems and individuals.

Current interventions for the treatment of major musculoskeletal diseases \& their limitations

- Osteoarthritis: Current surgical interventions such as mosaicplasty and autologous chondrocyte implantation produce fibrous repair cartilage, and do not offer long-term treatment solutions. Joint replacement surgery is a late-stage treatment option.

- Osteoporosis: Current pharmacological interventions may be effective but typically require life-long administration and can have side effects.

- Myopathies: Currently, there are no approved drugs or exercise interventions that consistently result in an increase in both muscle mass and strength.

Pluripotent stem cells: a promising alternative for musculoskeletal regeneration

- There are two known types of pluripotent stem cells (PSCs): embryonic stem cells and induced PSCs.

- Due to their capacity to differentiate into any somatic cell type, and ability to proliferate indefinitely in vitro without undergoing cellular senescence, PSCs are an idea candidate cell type for regenerative medicine.

PSCs \& chondrogenic, osteogenic, myogenic \& adipogenic differentiation

- The most commonly used methods for differentiation into mesodermal lineages are:

- via embryoid body formation

- via mesenchymal stem cell intermediates

- co-culture

- genetic manipulation

- growth factor addition.

- There is a requirement for clinically compliant differentiation protocols for clinical translation.

From cell-based strategies to tissue engineering 3D constructs

- A tissue engineering approach mitigates the risk of transferring undifferentiated cells to the patient, and enables the assessment of tissue quality prior to implantation.

Future perspective

- Future work will most likely involve tissue engineering rather than cell transplantation, and will require clinically compliant methods of cell derivation.

Financial \& competing interests disclosure

The authors acknowledge funding to RS Tare and FD Houghton from the Rosetrees Trust, the Faculty of Medicine and the Institute for Life Sciences, University of Southampton for PhD Studentship support to LA Jevons. FD Houghton also acknowledges funding from the Medical Research Council (G0701153). The authors have no other relevant affiliations or financial involvement with any organization or entity with a financial interest in or financial conflict with the subject matter or materials discussed in the manuscript apart from those disclosed.

No writing assistance was utilized in the production of this manuscript.

Open access

This work is licensed under the Creative Commons Attribution 4.0 License. To view a copy of this license, visit http://creativecomm ons.org/licenses/by/4.0/ 


\section{References}

Papers of special note have been highlighted as: $\bullet$ of interest; $\bullet \bullet$ of considerable interest

1. Nedergaard A, Henriksen K, Karsdal MA, Christiansen C. Musculoskeletal ageing and primary prevention. Best Practice Res. Clin. Obstetr. Gynaecol. 27(5), 673-688 (2013).

2. Woolf AD, Pfleger B. Burden of major musculoskeletal conditions. Bull. WHO 81(9), 646-656 (2003).

3. Malafarina V, Úriz-Otano F, Iniesta R, Gil-Guerrero L. Sarcopenia in the elderly: diagnosis, physiopathology and treatment. Maturitas 71(2), 109-114 (2012).

4. Rodino-Klapac LR, Mendell JR, Sahenk Z. Update on the treatment of Duchenne muscular dystrophy. Curr. Neurol. Neurosci. Rep. 13(3), 1-7 (2013).

5. Hunter DJ, Neogi T, Hochberg MC. Quality of osteoarthritis management and the need for reform in the US. Arthritis Care Res. (Hoboken) 63(1), 31-38 (2011).

6. Antebi B, Pelled G, Gazit D. Stem cell therapy for osteoporosis. Curr. Osteoporos. Rep. 12(1), 41-47 (2014).

7. Dargent-Molina P, Favier F, Grandjean $\mathrm{H}$ et al. Fall-related factors and risk of hip fracture: the EPIDOS prospective study. Lancet 348(9021), 145-149 (1996).

8. Landi F, Liperoti R, Russo A et al. Sarcopenia as a risk factor for falls in elderly individuals: results from the ilSIRENTE study. Clin. Nutr. 31(5), 652-658 (2012).

9. Johnell O, Kanis J. An estimate of the worldwide prevalence, mortality and disability associated with hip fracture. Osteoporosis Int. 15(11), 897-902 (2004).

10. Control CFD, Prevention. Prevalence of doctor-diagnosed arthritis and arthritis-attributable activity limitation - United States, 2007-2009. Morb. Mortal. Week. Rep. 59(39), 1261 (2010).

11. Cross M, Smith E, Hoy D et al. The global burden of hip and knee osteoarthritis: estimates from the global burden of disease 2010 study. Ann. Rheum. Dis. 73(7), 1323-1330 (2014).

12. Pritzker K, Gay S, Jimenez S et al. Osteoarthritis cartilage histopathology: grading and staging. Osteoarthritis Cartilage 14(1), 13-29 (2006).

13. D'apuzzo MR, Pao AW, Novicoff WM, Browne JA. Age as an independent risk factor for postoperative morbidity and mortality after total joint arthroplasty in patients 90 years of age or older. J. Arthroplasty 29(3), 477-480 (2014).

14. Johnson LL. Arthroscopic abrasion arthroplasty: a review. Clin. Orthop. Relat. Res. 391, S306-S317 (2001).

15. Insall J. The Pridie debridement operation for osteoarthritis of the knee. Clin. Orthop. Relat. Res. 101, 61-67 (1974).

16. Mithoefer K, Williams RJ, Warren RF et al. Chondral resurfacing of articular cartilage defects in the knee with the microfracture technique. J. Bone Joint Surg. Am. 88(1 Suppl. 2), 294-304 (2006).

17. Bentley G, Biant L, Vijayan S, Macmull S, Skinner J, Carrington R. Minimum ten-year results of a prospective randomised study of autologous chondrocyte implantation versus mosaicplasty for symptomatic articular cartilage lesions of the knee. J. Bone Joint Surg. Br. 94(4), 504-509 (2012).

18. Brittberg M, Lindahl A, Nilsson A, Ohlsson C, Isaksson O, Peterson L. Treatment of deep cartilage defects in the knee with autologous chondrocyte transplantation. N. Engl. J. Med. 331(14), 889-895 (1994).

19. Hernlund E, Svedbom A, Ivergård M et al. Osteoporosis in the European Union: medical management, epidemiology and economic burden. Arch. Osteoporos. 8(1-2), 1-115 (2013).

20. Johnell O, Kanis J. An estimate of the worldwide prevalence and disability associated with osteoporotic fractures. Osteoporosis Int. 17(12), 1726-1733 (2006).

21. Kanis JA. Assessment of fracture risk and its application to screening for postmenopausal osteoporosis: synopsis of a WHO report. Osteoporosis Int. 4(6), 368-381 (1994).

22. Tsai JN, Uihlein AV, Lee $\mathrm{H}$ et al. Teriparatide and denosumab, alone or combined, in women with postmenopausal osteoporosis: the DATA study randomised trial. Lancet 382(9886), 50-56 (2013).

23. Khan AA, Sandor GK, Dore E et al. Bisphosphonate associated osteonecrosis of the jaw. J. Rheumatol. 36(3), 478-490 (2009).

24. Nieves JW, Cosman F. Atypical subtrochanteric and femoral shaft fractures and possible association with bisphosphonates. Curr. Osteoporos. Rep. 8(1), 34-39 (2010).

25. Patel HP, Syddall HE, Jameson K et al. Prevalence of sarcopenia in community-dwelling older people in the UK using the European Working Group on Sarcopenia in Older People (EWGSOP) definition: findings from the Hertfordshire Cohort Study (HCS). Age Ageing 42(3), 378-384 (2013).

26. Emery AE. The muscular dystrophies. Lancet 359(9307), 687-695 (2002).

27. Mauro A. Satellite cell of skeletal muscle fibers. J. Biophys. Biochem. Cytol. 9(2), 493-495 (1961).

28. Webster C, Blau HM. Accelerated age-related decline in replicative life-span of Duchenne muscular dystrophy myoblasts: implications for cell and gene therapy. Somatic Cell Mol. Genet. 16(6), 557-565 (1990). 
29. Meriggioli MN, Roubenoff R. Prospect for pharmacological therapies to treat skeletal muscle dysfunction. Calcif. Tissue Int. 96(3), 234-242 (2015).

30. Murphy L, Schwartz TA, Helmick CG et al. Lifetime risk of symptomatic knee osteoarthritis. Arthritis Care Res. (Hoboken) 59(9), 1207-1213 (2008).

31. Redman S, Oldfield S, Archer C. Current strategies for articular cartilage repair. Eur. Cells Mater. 9(23-32), 23-32 (2005).

32. Horas U, Pelinkovic D, Herr G, Aigner T, Schnettler R. Autologous chondrocyte implantation and osteochondral cylinder transplantation in cartilage repair of the knee joint. J. Bone Joint Surg. 85(2), 185-192 (2003).

33. Roberts J, Castro C, Moore A, Fogelman I, Hampson G. Changes in bone mineral density and bone turnover in patients on 'drug holiday' following bisphosphonate therapy: real-life clinic setting. Clin. Endocrinol. (Oxf.) 84(4), 509-515 (2016).

34. Dooley J, Gordon KE, Dodds L, Macsween J. Duchenne muscular dystrophy: a 30-year population-based incidence study. Clin. Pediatr. (Phila.) 49(2), 177-179 (2010).

35. Hasten DL, Pak-Loduca J, Obert KA, Yarasheski KE. Resistance exercise acutely increases MHC and mixed muscle protein synthesis rates in 78-84 and 23-32 yr olds. Am. J. Physiol. Endocrinol. Metabol. 278(4), E620-E626 (2000).

36. Gloss D, Moxley RT, Ashwal S, Oskoui M. Practice guideline update summary: corticosteroid treatment of Duchenne muscular dystrophy report of the Guideline Development Subcommittee of the American Academy of Neurology. Neurology 86(5), 465-472 (2016).

37. Fairclough RJ, Wood MJ, Davies KE. Therapy for Duchenne muscular dystrophy: renewed optimism from genetic approaches. Nat. Rev. Genet. 14(6), 373-378 (2013).

38. Vangsness CTJ, Farr JI, Boyd J, Dellaero DT, Mills CR, Leroux-Williams M. Adult human mesenchymal stem cells delivered via intra-articular injection to the knee following partial medial meniscectomy: a randomized, double-blind, controlled study. J. Bone Joint Surg. Am. 96(2), 90-98 (2014).

39. Law $\mathrm{P}$, Bertorini $\mathrm{T}$, Goodwin $\mathrm{T}$ et al. Dystrophin production induced by myoblast transfer therapy in Duchenne muscular dystrophy. Lancet 336(8707), 114-115 (1990).

40. Huang G-J, Gronthos S, Shi S. Mesenchymal stem cells derived from dental tissues vs. those from other sources: their biology and role in regenerative medicine. J. Dent. Res. 88(9), 792-806 (2009).

41. Pittenger MF, Mackay AM, Beck SC et al. Multilineage potential of adult human mesenchymal stem cells. Science 284(5411), 143-147 (1999).

42. Phinney DG, Kopen G, Righter W, Webster S, Tremain N, Prockop DJ. Donor variation in the growth properties and osteogenic potential of human marrow stromal cells. J. Cell. Biochem. 75(3), 424-436 (1999).

43. Stenderup K, Justesen J, Clausen C, Kassem M. Aging is associated with decreased maximal life span and accelerated senescence of bone marrow stromal cells. Bone 33(6), 919-926 (2003).

44. Sethe S, Scutt A, Stolzing A. Aging of mesenchymal stem cells. Ageing Res. Rev. 5(1), 91-116 (2006).

45. Caplan AI, Sorrell JM. The MSC curtain that stops the immune system. Immunol. Lett. 168(2), 136-139 (2015).

46. Davatchi F, Abdollahi BS, Mohyeddin M, Shahram F, Nikbin B. Mesenchymal stem cell therapy for knee osteoarthritis. Preliminary report of four patients. Int. J. Rheum. Dis. 14(2), 211-215 (2011).

47. Mohsen Emadedin M, Roghayeh Fazeli M, Reza Farjad M. Intra-articular injection of autologous mesenchymal stem cells in six patients with knee osteoarthritis. Arch. Iran. Med. 15(7), 422 (2012).

48. Johnstone B, Hering T, Caplan A, Goldberg V, Yoo J. In vitro chondrogenesis of bone marrow-derived mesenchymal progenitor cells. Exp. Cell Res. 238(1), 265-272 (1998).

49. Yoo JU, Barthel TS, Nishimura K et al. The chondrogenic potential of human bone-marrow-derived mesenchymal progenitor cells. J. Bone Joint Surg. 80(12), 1745-1757 (1998).

50. Morandi L, Bernasconi P, Gebbia M et al. Lack of mRNA and dystrophin expression in DMD patients three months after myoblast transfer. Neuromuscul. Disord. 5(4), 291-295 (1995).

51. Gussoni E, Pavlatht GK, Lanctoti AM, Sharmaii KR. Normal dystrophin transcripts detected in Duchenne muscular dystrophy patients after myoblast transplantation. Nature 356, 2 (1992).

52. Thomson JA, Itskovitz-Eldor J, Shapiro SS et al. Embryonic stem cell lines derived from human blastocysts. Science 282(5391), 1145-1147 (1998).

- First demonstrated the generation of human embryonic stem cell (hESC) lines from human blastocyts.

53. Takahashi K, Yamanaka S. Induction of pluripotent stem cells from mouse embryonic and adult fibroblast cultures by defined factors. Cell 126(4), 663-676 (2006).

54. Kuroda Y, Kitada M, Wakao S et al. Unique multipotent cells in adult human mesenchymal cell populations. Proc. Natl Acad. Sci. USA 107(19), 8639-8643 (2010).

55. Grinnemo K-H, Kumagai-Braesch M, Mânsson-Broberg A et al. Human embryonic stem cells are immunogenic in allogeneic and xenogeneic settings. Reprod. Biomed. Online 13(5), 712-724 (2006). 
56. Li L, Baroja ML, Majumdar A et al. Human embryonic stem cells possess immune-privileged properties. Stem Cells 22(4), 448-456 (2004).

57. Araki R, Uda M, Hoki Y et al. Negligible immunogenicity of terminally differentiated cells derived from induced pluripotent or embryonic stem cells. Nature 494(7435), 100-104 (2013).

58. Nakajima F, Tokunaga K, Nakatsuji N. Human leukocyte antigen matching estimations in a hypothetical bank of human embryonic stem cell lines in the Japanese population for use in cell transplantation therapy. Stem Cells 25(4), 983-985 (2007).

59. Draper JS, Smith K, Gokhale P et al. Recurrent gain of chromosomes $17 \mathrm{q}$ and 12 in cultured human embryonic stem cells. Nat. Biotechnol. 22(1), 53 (2004).

60. Ilic D, Devito L, Miere C, Codognotto S. Human embryonic and induced pluripotent stem cells in clinical trials. Br. Med. Bull. Idv045 (2015).

61. Schwartz SD, Hubschman J-P, Heilwell G et al. Embryonic stem cell trials for macular degeneration: a preliminary report. Lancet 379(9817), 713-720 (2012).

62. Takahashi $\mathrm{K}$, Tanabe $\mathrm{K}$, Ohnuki $\mathrm{M}$ et al. Induction of pluripotent stem cells from adult human fibroblasts by defined factors. Cell 131(5), 861-872 (2007).

- The revolutionary paper that first demonstrated the reprogramming of somatic cells to a pluripotent state.

63. Doi A, Park I-H, Wen B et al. Differential methylation of tissue-and cancer-specific CpG island shores distinguishes human induced pluripotent stem cells, embryonic stem cells and fibroblasts. Nat. Genet. 41(12), 1350-1353 (2009).

64. Yu J, Hu K, Smuga-Otto K et al. Human induced pluripotent stem cells free of vector and transgene sequences. Science 324(5928), 797-801 (2009).

65. Kim D, Kim C-H, Moon J-I et al. Generation of human induced pluripotent stem cells by direct delivery of reprogramming proteins. Cell Stem Cell 4(6), 472 (2009).

66. Okita K, Matsumura Y, Sato Y et al. A more efficient method to generate integration-free human iPS cells. Nat. Methods 8(5), 409-412 (2011).

67. Fusaki N, Ban H, Nishiyama A, Saeki K, Hasegawa M. Efficient induction of transgene-free human pluripotent stem cells using a vector based on Sendai virus, an RNA virus that does not integrate into the host genome. Proc. Jpn. Acad. Ser. B Phys. Biol. Sci. 85(8), 348-362 (2009).

68. Li MD, Atkins H, Bubela T. The global landscape of stem cell clinical trials. Regen. Med. 9(1), 27-39 (2014).

69. Kim K, Doi A, Wen B et al. Epigenetic memory in induced pluripotent stem cells. Nature 467(7313), 285-290 (2010).

70. Toh WS, Yang Z, Liu H, Heng BC, Lee EH, Cao T. Effects of culture conditions and bone morphogenetic protein 2 on extent of chondrogenesis from human embryonic stem cells. Stem Cells 25(4), 950-960 (2007).

71. Yodmuang S, Marolt D, Marcos-Campos I, Gadjanski I, Vunjak-Novakovic G. Synergistic effects of hypoxia and morphogenetic factors on early chondrogenic commitment of human embryonic stem cells in embryoid body culture. Stem Cell Rev. Rep. 11(2), 228-241 (2015).

72. Forristal CE, Wright KL, Hanley NA, Oreffo RO, Houghton FD. Hypoxia inducible factors regulate pluripotency and proliferation in human embryonic stem cells cultured at reduced oxygen tensions. Reproduction 139(1), 85-97 (2010).

73. Yang Z, Sui L, Toh WS, Lee EH, Cao T. Stage-dependent effect of TGF- $\beta 1$ on chondrogenic differentiation of human embryonic stem cells. Stem Cells Dev. 18(6), 929-940 (2009).

74. Kramer J, Hegert C, Guan K, Wobus AM, Müller PK, Rohwedel J. Embryonic stem cell-derived chondrogenic differentiation in vitro: activation by BMP-2 and BMP-4. Mech. Dev. 92(2), 193-205 (2000).

75. Mackay AM, Beck SC, Murphy JM, Barry FP, Chichester CO, Pittenger MF. Chondrogenic differentiation of cultured human mesenchymal stem cells from marrow. Tissue Eng. 4(4), 415-428 (1998).

76. Zhang L, Su P, Xu C, Yang J, Yu W, Huang D. Chondrogenic differentiation of human mesenchymal stem cells: a comparison between micromass and pellet culture systems. Biotechnol. Lett. 32(9), 1339-1346 (2010).

77. Kim MJ, Son MJ, Son MY et al. Generation of human induced pluripotent stem cells from osteoarthritis patient-derived synovial cells. Arthritis Rheum. 63(10), 3010-3021 (2011).

78. Wei Y, Zeng W, Wan R et al. Chondrogenic differentiation of induced pluripotent stem cells from osteoarthritic chondrocytes in alginate matrix. Eur. Cells Mater. 23, 1-12 (2012).

79. Ko J-Y, Kim K-I, Park S, Im G-I. In vitro chondrogenesis and in vivo repair of osteochondral defect with human induced pluripotent stem cells. Biomaterials 35(11), 3571-3581 (2014).

80. Vats A, Bielby RC, Tolley $\mathrm{N}$ et al. Chondrogenic differentiation of human embryonic stem cells: the effect of the micro-environment. Tissue Eng. 12(6), 1687-1697 (2006).

81. Hwang NS, Varghese S, Elisseeff J. Derivation of chondrogenically-committed cells from human embryonic cells for cartilage tissue regeneration. PLoS ONE 3(6), e2498 (2008). 
82. Fischer J, Dickhut A, Rickert M, Richter W. Human articular chondrocytes secrete parathyroid hormone-related protein and inhibit hypertrophy of mesenchymal stem cells in coculture during chondrogenesis. Arthritis Rheum. 62(9), 2696-2706 (2010).

83. Hoben GM, Willard VP, Athanasiou KA. Fibrochondrogenesis of hESCs: growth factor combinations and cocultures. Stem Cells Dev. 18(2), 283-292 (2009).

84. Bigdeli N, Karlsson C, Strehl R, Concaro S, Hyllner J, Lindahl A. Coculture of human embryonic stem cells and human articular chondrocytes results in significantly altered phenotype and improved chondrogenic differentiation. Stem Cells 27(8), 1812-1821 (2009).

85. Tare RS, Howard D, Pound JC, Roach HI, Oreffo RO. Tissue engineering strategies for cartilage generation—micromass and three dimensional cultures using human chondrocytes and a continuous cell line. Biochem. Biophys. Res. Commun. 333(2), 609-621 (2005).

86. Kafienah W, Mistry S, Dickinson SC, Sims TJ, Learmonth I, Hollander AP. Three-dimensional cartilage tissue engineering using adult stem cells from osteoarthritis patients. Arthritis Rheum. 56(1), 177-187 (2007).

87. Barberi T, Willis LM, Socci ND, Studer L. Derivation of multipotent mesenchymal precursors from human embryonic stem cells. PLoS Med. 2(6), 554 (2005).

88. Lian Q, Lye E, Suan Yeo K et al. Derivation of clinically compliant MSCs from CD105+, CD24- differentiated human ESCs. Stem Cells 25(2), 425-436 (2007).

- Isolation of a pure osteoblast population from differentiated hESCs using a Col2.3GFP reporter.

89. Oldershaw RA, Baxter MA, Lowe ET et al. Directed differentiation of human embryonic stem cells toward chondrocytes. Nat. Biotechnol. 28(11), 1187-1194 (2010).

-. Reports a chemically defined and scalable protocol for the directed differentiation of hESCs toward chondrocytes that mimics developmental chondrogenesis.

90. Oldershaw RA, Baxter MA, Lowe ET et al. Chondrocyte protocol. In: StemBook. Harvard Stem Cell Institute, Cambridge, MA (2010).

91. Cheng A, Kapacee Z, Peng J et al. Cartilage repair using human embryonic stem cell-derived chondroprogenitors. Stem Cells Transl. Med. 3(11), 1287-1294 (2014).

92. Sottile V, Thomson A, Mcwhir J. In vitro osteogenic differentiation of human ES cells. Cloning Stem Cells 5(2), 149-155 (2003).

93. Bielby RC, Boccaccini AR, Polak JM, Buttery LD. In vitro differentiation and in vivo mineralization of osteogenic cells derived from human embryonic stem cells. Tissue Eng. 10(9-10), 1518-1525 (2004).

94. Karp JM, Ferreira LS, Khademhosseini A, Kwon AH, Yeh J, Langer RS. Cultivation of human embryonic stem cells without the embryoid body step enhances osteogenesis in vitro. Stem Cells 24(4), 835-843 (2006).

95. Xin X, Jiang X, Wang L et al. A site-specific integrated Col2. 3GFP reporter identifies osteoblasts within mineralized tissue formed in vivo by human embryonic stem cells. Stem Cells Transl. Med. 3(10), 1125 (2014).

- Isolation of a pure osteoblast population from differentiated hESCs using a Col2.3GFP reporter.

96. Robey PG, Kuznetsov SA, Riminucci M, Bianco P. Bone marrow stromal cell assays: in vitro and in vivo. In: Skeletal Development and Repair: Methods and Protocols. Springer, NY, USA, 279-293 (2014).

97. Ahn SE, Kim S, Park KH et al. Primary bone-derived cells induce osteogenic differentiation without exogenous factors in human embryonic stem cells. Biochem. Biophys. Res. Commun. 340(2), 403-408 (2006).

98. Inanç B, Elçin AE, Elçin YM. Effect of osteogenic induction on the in vitro differentiation of human embryonic stem cells cocultured with periodontal ligament fibroblasts. Artif. Organs 31(11), 792-800 (2007).

99. Tong W, Brown SE, Krebsbach PH. Human embryonic stem cells undergo osteogenic differentiation in human bone marrow stromal cell microenvironments. J. Stem Cells 2(3), 139 (2007).

100. Heng BC, Toh WS, Pereira BP et al. An autologous cell lysate extract from human embryonic stem cell (hESC) derived osteoblasts can enhance osteogenesis of hESC. Tissue Cell 40(3), 219-228 (2008).

101. Neumeyer A, Cross D, Mckenna-Yasek D et al. Pilot study of myoblast transfer in the treatment of Becker muscular dystrophy. Neurology 51(2), 589-592 (1998).

102. Karpati G, Ajdukovic D, Arnold D et al. Myoblast transfer in Duchenne muscular dystrophy. Ann. Neurol. 34(1), 8-17 (1993).

103. Law PK, Goodwin TG, Fang Q et al. Myoblast transfer therapy for Duchenne muscular dystrophy. Pediatr. Int. 33(2), 206-215 (1991).

104. Rohwedel J, Maltsev V, Bober E, Arnold H-H, Hescheler J, Wobus A. Muscle cell differentiation of embryonic stem cells reflects myogenesis in vivo: developmentally regulated expression of myogenic determination genes and functional expression of ionic currents. Dev. Biol. 164(1), 87-101 (1994).

105. Zheng JK, Wang Y, Karandikar A et al. Skeletal myogenesis by human embryonic stem cells. Cell Res. 16(8), 713-722 (2006).

106. Darabi R, Gehlbach K, Bachoo RM et al. Functional skeletal muscle regeneration from differentiating embryonic stem cells. Nat. Med. 14(2), 134-143 (2008).

107. Bhagavati S, Xu W. Generation of skeletal muscle from transplanted embryonic stem cells in dystrophic mice. Biochem. Biophys. Res. Commun. 333(2), 644-649 (2005). 
108. Barberi T, Bradbury M, Dincer Z, Panagiotakos G, Socci ND, Studer L. Derivation of engraftable skeletal myoblasts from human embryonic stem cells. Nat. Med. 13(5), 642-648 (2007).

109. Darabi R, Baik J, Clee M, Kyba M, Tupler R, Perlingeiro RC. Engraftment of embryonic stem cell-derived myogenic progenitors in a dominant model of muscular dystrophy. Exp. Neurol. 220(1), 212-216 (2009).

110. Darabi R, Santos FN, Filareto A et al. Assessment of the myogenic stem cell compartment following transplantation of Pax3/Pax7-induced embryonic stem cell-derived progenitors. Stem Cells 29(5), 777-790 (2011).

111. Darabi R, Arpke RW, Irion S et al. Human ES-and iPS-derived myogenic progenitors restore DYSTROPHIN and improve contractility upon transplantation in dystrophic mice. Cell Stem Cell 10(5), 610-619 (2012).

- Here, it was demonstrated that conditional expression of PAX7 in hESCs/inducedpluripotent stem cells can be used to derive large quantities of myogenicprecursors capable of engraftment and long-term survival in a dystrophic mousemodel. Notably, they achieved an improvement in muscle function.

112. Perini I, Elia I, Nigro AL et al. Myogenic induction of adult and pluripotent stem cells using recombinant proteins. Biochem. Biophys. Res. Commun. 464(3), 755-761 (2015).

113. Shoji E, Woltjen K, Sakurai H. Directed myogenic differentiation of human induced pluripotent stem cells. Methods Mol. Biol. 1353, 89-99 (2016).

114. Lian Q, Zhang Y, Zhang J et al. Functional mesenchymal stem cells derived from human induced pluripotent stem cells attenuate limb ischemia in mice. Circulation 121(9), 1113-1123 (2010).

115. Quattrocelli M, Palazzolo G, Floris G et al. Intrinsic cell memory reinforces myogenic commitment of pericyte-derived iPSCs. J. Pathol. 223(5), 593-603 (2011).

116. Choi JH, Gimble JM, Lee K et al. Adipose tissue engineering for soft tissue regeneration. Tissue Eng. B. Rev. 16(4), 413-426 (2010).

117. Ahfeldt T, Schinzel RT, Lee Y-K et al. Programming human pluripotent stem cells into white and brown adipocytes. Nat. Cell Biol. 14(2), 209-219 (2012).

118. Nishio M, Yoneshiro T, Nakahara M et al. Production of functional classical brown adipocytes from human pluripotent stem cells using specific hemopoietin cocktail without gene transfer. Cell Metab. 16(3), 394-406 (2012).

- Describes an efficient method for the generation of functional brown adipocytesfrom pluripotent stem cells without using exogenous gene transfer. Here, theydemonstrated that key differences in signaling pathways exist between hESC andinduced pluripotent stem cell-derived brown adipocytes.

119. Taura D, Noguchi M, Sone M et al. Adipogenic differentiation of human induced pluripotent stem cells: comparison with that of human embryonic stem cells. FEBS Lett. 583(6), 1029-1033 (2009).

120. Zur Nieden NI, Kempka G, Rancourt DE, Ahr H-J. Induction of chondro-, osteo-and adipogenesis in embryonic stem cells by bone morphogenetic protein-2: effect of cofactors on differentiating lineages. BMC Dev. Biol. 5(1), 1 (2005).

121. Cypess AM, Lehman S, Williams G et al. Identification and importance of brown adipose tissue in adult humans. N. Engl. J. Med. 360(15), 1509-1517 (2009).

122. Saito M, Okamatsu-Ogura $\mathrm{Y}$, Matsushita $\mathrm{M}$ et al. High incidence of metabolically active brown adipose tissue in healthy adult humans effects of cold exposure and adiposity. Diabetes 58(7), 1526-1531 (2009).

123. Virtanen KA, Lidell ME, Orava J et al. Functional brown adipose tissue in healthy adults. N. Engl. J. Med. 360(15), 1518-1525 (2009).

124. De Peppo GM, Marcos-Campos I, Kahler DJ et al. Engineering bone tissue substitutes from human induced pluripotent stem cells. Proc. Natl Acad. Sci. USA 110(21), 8680-8685 (2013).

125. Marolt D, Campos IM, Bhumiratana S et al. Engineering bone tissue from human embryonic stem cells. Proc. Natl Acad. Sci. USA 109(22), 8705-8709 (2012).

126. Jin GZ, Kim TH, Kim JH et al. Bone tissue engineering of induced pluripotent stem cells cultured with macrochanneled polymer scaffold. J. Biomed. Mater. Res. A 101(5), 1283-1291 (2013).

127. Wen C, Kang H, Shih Y-RV, Hwang Y, Varghese S. In vivo comparison of biomineralized scaffold-directed osteogenic differentiation of human embryonic and mesenchymal stem cells. Drug Deliv. Transl. Res. 6(2), 121-131 (2015).

128. Qazi TH, Mooney DJ, Pumberger M, Geißler S, Duda GN. Biomaterials based strategies for skeletal muscle tissue engineering: existing technologies and future trends. Biomaterials 53, 502-521 (2015).

129. Chal J, Al Tanoury Z, Hestin M et al. Generation of human muscle fibers and satellite-like cells from human pluripotent stem cells in vitro. Nat. Protoc. 11(10), 1833-1850 (2016). 